\title{
Assessment of the relationship between intraabdominal fat thickness and the aortomesenteric angle and distance using computed tomography
}

\section{İntraabdominal yağ doku kalınlığı ille aortomezenterik açı ve uzaklık değerleri arasındaki ilişkinin bilgisayarlı tomografi ile değerlendirilmesi}

Eda Albayrak ${ }^{1}$, Osman Demir ${ }^{2}$

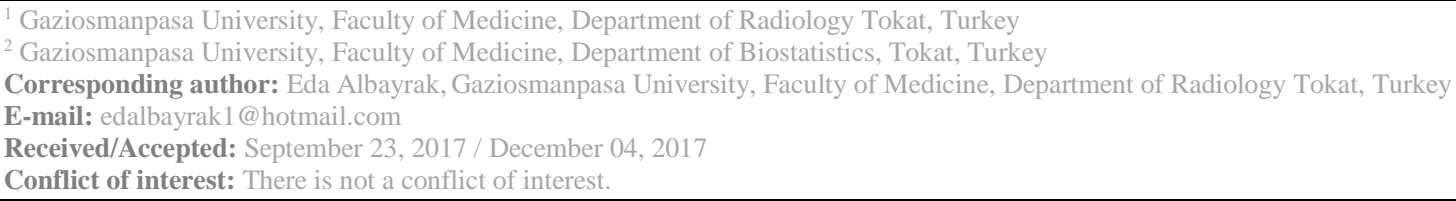

\section{SUMMARY}

Objective: The aim of this study is to evaluate the effect of visceral fat thickness on the distance and angle between the superior mesenteric artery (SMA) and the aorta in the normal population.

Method: The aortomesenteric distance and retroperitoneal fat thickness (RFT) were measured on an axial plane, and the aortomesenteric angle and mesenteric fat thickness (MFT) were measured on a sagittal plane using multidetector computed tomography (MDCT). The relationships between MFT, RFT and aortomesenteric angle and distance were evaluated.

Results: There was a weak/moderate, significant and positive correlation between aortomesenteric angle and MFT and RFT ( $r=0,396, p<0.001$ and $r=0,494, p<0.001$, respectively). There was also a moderate, significant and positive correlation between aortomesenteric distance and RFT and MFT $(r=0,607, p<0.001$ and $r=0,633$, p $<0.001$, respectively). Conclusion: The aortomesenteric distance and angle correlate with the retroperitoneal and mesenteric fat thickness. According to the results, retroperitoneal and mesenteric fat thickness may be used as an CT marker to help diagnose suspected SMAS in addition to the measurements of the aortomesenteric distance and angle.

Keywords: Superior mesenteric artery, multidetector computed tomography, mesenteric fat, retroperitoneal fat.

\section{ÖZET}

Amaç: Çalışmamızın amacı, normal populasyonda, visseral yağ doku kalınlığının, superior mezenterik arter (SMA) ile aorta arasındaki açıya ve uzaklığa olan etkisini araştırmaktır.

Yöntem: Ölçümler çok kesitli bilgisayarlı tomografi (ÇKBT) cihazı kullanılarak gerçekleştirildi. Aortomezenterik uzaklık ve retroperitoneal yağ doku kalınlığı (RYK) aksiyal kesitlerde, aortomezenterik açı ve mezenterik yağ doku kalınlığı (MYK) sagital kesitlerde ölçüldü. MYK ve RYK ile aortomezenterik açı ve uzaklık arasındaki ilişki araştırıldı. Bulgular: Aortomezenterik açı ile MYK ve RYK arasında sırasıyla zayıf/orta düzeyde pozitif yönlü ilişki tespit edilmiştir $(\mathrm{r}=0,396, \mathrm{p}<0.001$ ve $\mathrm{r}=0,494, \mathrm{p}<0.001)$. Aortomezenterik uzakl1k ile RYK ve MYK arasında ise orta düzeyde pozitif yönlü bir ilişki tespit edilmiştir $(r=0,607, p<0.001$ ve $r=0,633, p<0.001)$.

Sonuç: Aortomesenterik açı ve uzaklık ile visceral yağ doku kalınlıkları arasında pozitif yönlü anlamlı bir ilişki vardır. Bu sonuçlara göre ÇKBT ile ölçülen, retroperitoneal ve mezenterik yağ doku kalınlıkları klinik olarak SMA sendromu düşünülen şüpheli vakaların tanısında aortomezenterik uzaklık ve açı ölçümlerine ek olarak bir BT belirteci olarak kullanilabilir.

Anahtar sözcükler: Superior mesenterik arter, çok kesitli bilgisayarlı tomografi, mesenterik yağ dokusu, retroperitoneal yağ dokusu. 


\section{INTRODUCTION}

Superior mesenteric artery syndrome (SMAS) is a rare gastrovascular disorder that results in proximal intestinal obstruction. Affected patients are characterized by a decreased angle between the overlaying superior mesenteric artery (SMA) and underlying abdominal aorta, thus resulting in compression of the third portion of the duodenum. 1

This syndrome typically occurs secondary to rapid weight loss. Significant weight loss decreases the amount of retroperitoneal fat between the superior mesenteric artery and the aorta, thus removing a major source of cushioning for the duodenum and allowing duodenal compression. ${ }^{2}$ Although there are several studiesthat mention the significance of the angle and distance between the SMA and the aorta in the etiology of SMAS, ${ }^{3-9}$ very few studies have been conducted to evaluate the association between the angle of SMA and the amount of intraabdominal fat in the normal population. ${ }^{10-12} \mathrm{In}$ such studies, body mass index (BMI) has frequently been used to estimate the amount of abdominal fat. ${ }^{11,12}$ However, BMI provides only an indirect assessment of adiposity, as BMI cannot differentiate between visceral and subcutaneous fat. ${ }^{13,}{ }^{14}$ Visceral abdominal fat measured with cross sectional imaging modality such as computed tomography (CT) or magnetic resonance imaging (MRI) represents the amount of abdominal fat directly and is more accurate than BMI. ${ }^{15-21}$ Thus, the aim of the present study is to evaluate the effect of visceral fat thickness on the distance and angle between the SMA and the aorta in the normal population using multidetector computed tomography (MDCT).

\section{METHODS}

Control and patients group were retrospectively selected among patients who were examined in our clinic with abdominal aorta computed tomography for various symptoms between 2015 and 2016. The patients' age, sex and clinical findings were obtained from the hospital database. The patients who had a history of abdominal surgery, suspect symptoms of SMAS, renal atrophy or hypertrophy, retroperitoneal cyst/ mass and abdominal aortic aneurysm at the level of the SMA origin were excluded.

CT examinations were carried out using 8- or 128slice MDCT scanners (LightSpeed Ultra; GE, Milwaukee, USA and GE Optima ${ }^{\mathrm{TM}}$ CT660; GE Healthcare) with the patient lying in a supine position. The parameters that were used in axial consecutive sections are respectively as follows: tube voltage: $100 \mathrm{kVp}$; tube current:290-398 mA; gantry rotation: $504-665 \mathrm{~ms}$; and slice thickness: $1.25 \mathrm{~mm}$.

Analysis of the images was performed using a computer monitor with Picture Archiving and Communication System (PACS) Workstation (Sectra AB, Linköping, Sweden), and sagittal or oblique-sagittal multiplanar reconstruction (MPR) images were created for assessment of the angle between the aorta and the SMA (Figure 1). The distance between the SMA and the aorta was measured on axial CT sections at a level where the duodenum was crossing (Figure 2). 


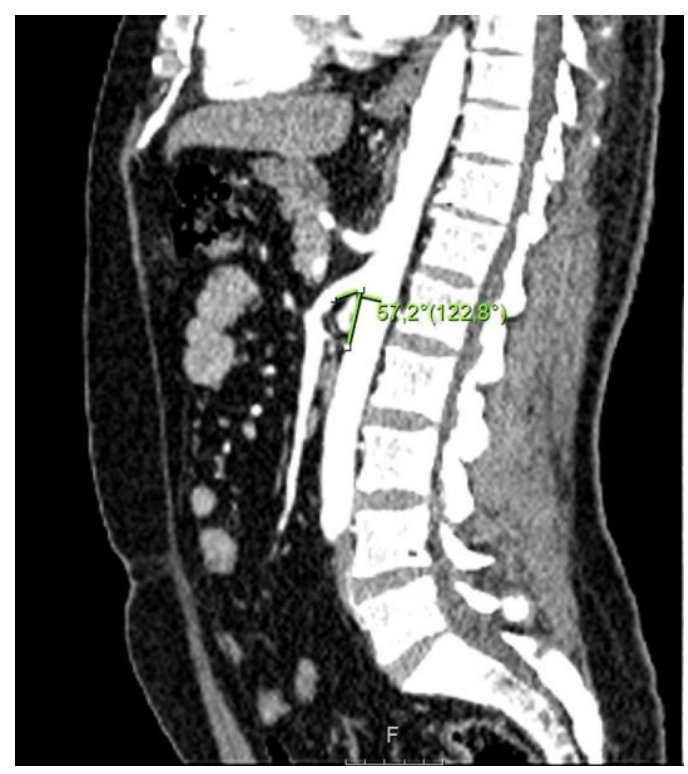

Figure 1: The measurement of the angle between the aorta and the SMA on a sagittal CT image

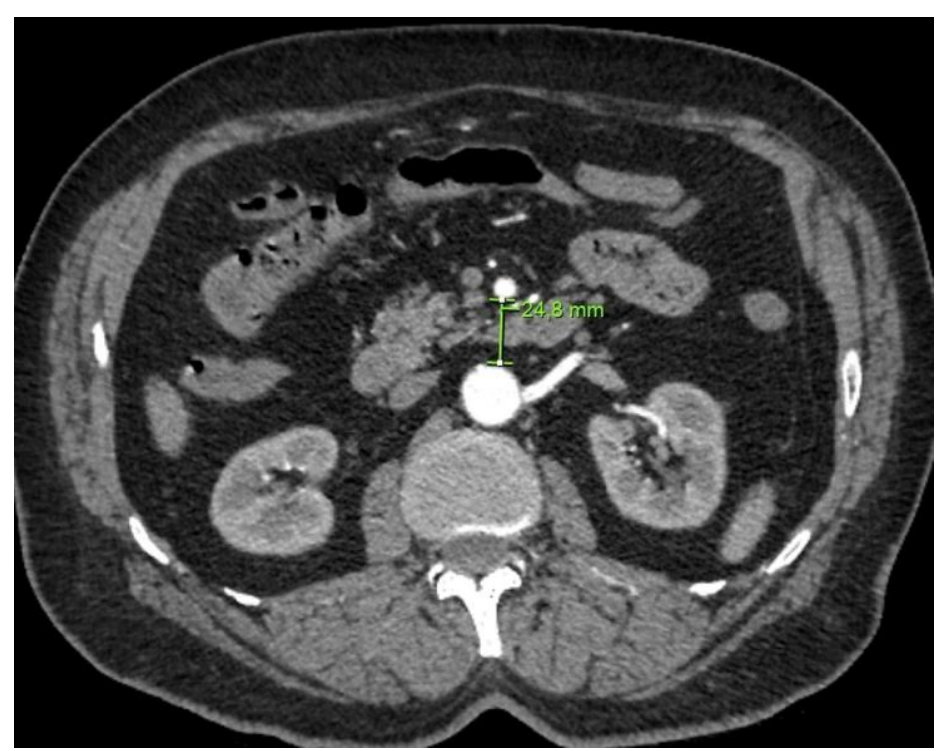

Figure 2: The measurement of aortomesenteric distance on an axial CT image
The amount of abdominal fat was expressed as mesenteric fat thickness (MFT) and retroperitoneal fat thickness (RFT). MFT was measured on the sagittal plane at the level of L3-L4 vertebrae. ${ }^{22}$ (Figure 3) RFT, which is considered a surrogate for visceral adipose tissue quantity, was quantified by measuring the vertical distance between the left posterior renal capsule and the junction of the abdominal wall and para-spinal musculature at the level of the left renal vein (Figure 4). All measurements were conducted by one radiologist, who had 14 years of experience in abdominal radiology.

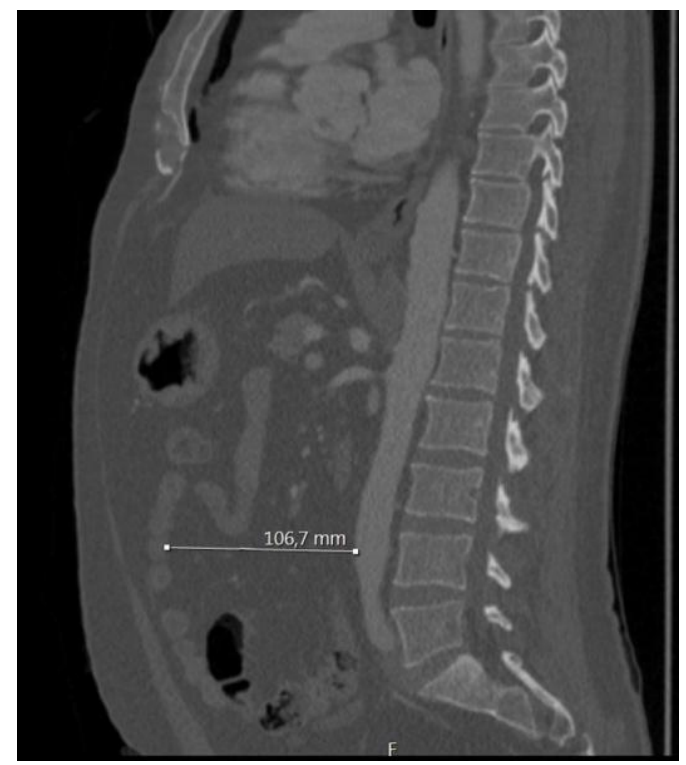

Figure 3: The measurement of the mesenteric fat thickness on a sagittal CT image 


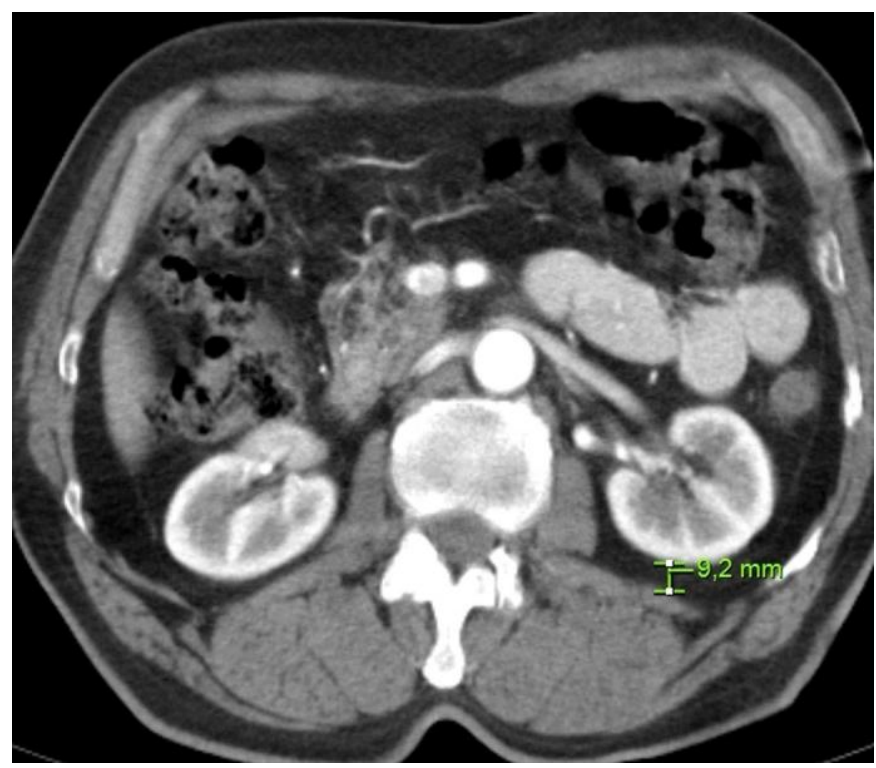

Figure 4: The measurement of the retroperitoneal fat thickness on an axial CT image

\section{Statistical Analysis;}

The quantitative variables were expressed as mean \pm standard deviation, and the qualitative variables were expressed as count and percentages. Independent sample t-tests were used to compare the continuous normal data between/among groups. The Pearson correlation coefficient was used to determine the strength and direction of the linear relationship among continuous variables.
$P$ values below 0.05 were accepted as statistically significant. Analyses were performed using SPSS 19 (IBM SPSS Statistics 19. SPSS inc., an IBM Co., Somers, NY).

\section{RESULTS}

In total, 82 individuals were included in the study. The general distribution of variables is presented in Table 1.

Table 1. General distributions of variables

\begin{tabular}{lccc}
\hline Variables & & Min. & Max. \\
\hline Gender $($ Female $(n \%) /$ Male $(n \%))$ & $37(45,1) / 45(54,9)$ & & \\
Age $($ Mean $\pm S D)$ & $56,41 \pm 12,94$ & 20,00 & 73,00 \\
Distance $($ Mean $\pm S D)(m m)$ & $18,84 \pm 5,61$ & 10,00 & 28,30 \\
RFT $($ Mean $\pm S D)(m m)$ & $14,55 \pm 7,8$ & 2,00 & 35,00 \\
Angle $($ Mean $\pm S D)($ degrees $)$ & $56,26 \pm 14,92$ & 20,00 & 70,40 \\
MFT $($ Mean $\pm S D)(m m)$ & $46,98 \pm 22,23$ & 11,40 & 106,70 \\
\hline
\end{tabular}

Table 2 summarizes the differences between the male and female group regarding quantitative variables. According to the results, there was no statistically significant difference between the groups regarding age, aortomesenteric distance, angle of SMA, RFT and MFT ( $p>0.05$ ). 
Table 2. Distributions of variables by gender

\begin{tabular}{lccc}
\hline & \multicolumn{2}{c}{ Gender } & $\mathrm{p}$ \\
\cline { 2 - 3 } & Female & Male & \\
\hline Age & $53,84 \pm 12,51$ & $58,53 \pm 13,04$ & 0,102 \\
Distance $(\mathrm{mm})$ & $18,68 \pm 5,61$ & $18,98 \pm 5,68$ & 0,813 \\
RFT $(\mathrm{mm})$ & $13,11 \pm 8,75$ & $15,74 \pm 6,8$ & 0,130 \\
Angle $($ degrees $)$ & $55,88 \pm 14,3$ & $56,58 \pm 15,57$ & 0,834 \\
MFT $(\mathrm{mm})$ & $47,88 \pm 23,7$ & $46,23 \pm 21,18$ & 0,741 \\
\hline
\end{tabular}

Table 3 shows the correlation among variables.According to the results, there was a weak/moderate, significant and positive correlation between aortomesenteric angle and MFT and RFT $(\mathrm{r}=0,396, \mathrm{p}<0.001$ and $\mathrm{r}=0,494, \mathrm{p}<0.001$, respectively). There was also a moderate, significant and positive correlation between

Table 3. Correlation among variables

\begin{tabular}{lcccc}
\hline & & Distance & RFT & Angle \\
\hline \multirow{2}{*}{ RFT $(\mathrm{mm})$} & $\mathrm{r}$ & 0,607 & & \\
\multirow{2}{*}{ Angle $($ degrees $)$} & $\mathrm{p}$ & $<\mathbf{0 , 0 0 1}$ & & \\
& $\mathrm{r}$ & 0,516 & 0,494 & \\
\multirow{2}{*}{ MFT $(\mathrm{mm})$} & $\mathrm{p}$ & $<\mathbf{0 , 0 0 1}$ & $<\mathbf{0 , 0 0 1}$ & \\
& $\mathrm{r}$ & 0,633 & 0,409 & 0,396 \\
& $\mathrm{p}$ & $<\mathbf{0 , 0 0 1}$ & $<\mathbf{0 , 0 0 1}$ & $<\mathbf{0 , 0 0 1}$ \\
\hline
\end{tabular}

\section{DISCUSSION}

SMAS are an uncommon cause of small bowel obstruction. In this syndrome, the third part of the duodenum is compressed between the SMA at its origin and the abdominal aorta due to decreased angulation, which leads to partial or complete obstruction. ${ }^{23}$ The SMA originates from the anterior aspect of the aorta, at the L1 and L2 levels of the vertebral body, just inferior to the origin of the celiac trunk and descends downwards at an acute angle into the mesentery. Between the SMA, in its ventral and caudal course and the aorta running posterior and parallel to it, the aortomesenteric angle is formed. ${ }^{11}$ In normal anatomy, the aortomesenteric angle and aortomesenteric distance is $25^{\circ}-60^{\circ}$ and $10-28 \mathrm{~mm}$, respectively ${ }^{6,24}$, and the results of the present study were consistent with the literature in terms of the aortomesenteric angle and aortomesenteric distance. The part of duodenum courses posteroinferiorly in relation to the SMA. Normally, the SMA is encased in retroperitoneal and mesenteric fat and lymphatic tissue at its origin, and this is important for maintaining a wide aortomesenteric angle and distance, which aortomesenteric distance and RFT and MFT ( $\mathrm{r}=$ $0,607, \mathrm{p}<0.001$ and $\mathrm{r}=0,633, \quad \mathrm{p}<0.001$, respectively).

There was a moderate, significant and positive correlation between RFT and MFT $(r=0,409$, $\mathrm{p}<0.001)$. provides protection to the duodenum from compression between the SMA and the aorta. Any loss in retroperitoneal fat may reduce that angle and lead to SMAS. ${ }^{6,24}$ The incidence of SMAS reported in some previous studies range from 0.1 to $0.3 \%$; however, the true incidence is unknown. ${ }^{6}$

Several factors that affect the aortomesenteric angle are listed. The most common is significant weight loss, which leads to the loss of retroperitoneal fat. SMAS are most commonly associated with severe debilitating illnesses, such as malignancy, malabsorption syndromes, AIDS, trauma andburns. ${ }^{25}$ Weight loss is not the only factor responsible for SMAS. Surgical intervention that distorts the anatomy can lead to this syndrome. Corrective spinal surgery for scoliosis and esophagectomy in are among the causes. Moreover, congenital short ligament of Treitz suspending the duodenum in an abnormally cephalic position has also been reported in the literature as a cause. ${ }^{25}$ Females between that ages of 10 to 40 years are more commonly affected. ${ }^{26}$ The patient may present with acute symptoms of intestinal obstruction or, more commonly, with chronic symptoms such as recurrent abdominal 
pain with cramps, early satiety and postprandial fullness. Sometimes, pain is aggravated by lying supine and relief is obtained by lying in the knee chest position; this maneuver increases the aortomesenteric angle with subsequent relief of bowel obstruction. ${ }^{27,28}$

SMAS diagnosis is challenging and often delayed due to its insidious onset. The diagnosis should be suspected based on clinical presentation and supported by radiological tests. Barium studies may show duodenal dilatation and sometimes gastric dilatation with slow gastroduodenojejunal transit. Contrast-enhanced CT or MR angiography enable visualization of the vascular compression of the duodenum and precise measurement of the aortomesenteric angle and distance. ${ }^{29}$ Recently, MDCT with MPRs and CT angiography have become valuable, noninvasive diagnostic tools. ${ }^{15}$, 30

In the literature, there has been a limited number of studies that assess the impact of the retroperitoneal fat tissue on the angle and distance between the SMA and the aorta in the normal population. ${ }^{10-12}$ BMI was used to estimate the amount of abdominal fat in these studies. ${ }^{11,12}$ The studies found a positive correlation between BMI and the aortomesenteric distance and angle. However, previous studies have shown that visceral abdominal fat, rather than BMI, is mainly related to obesity disorders. ${ }^{17-21}$ Obesity may be assessed by anthropometric measurements. BMI, waist circumference, waist to hip ratio, sagittal abdominal diameter and skinfold thickness are the most commonly used parameters for these types of measurements. ${ }^{13}$ Anthropometric techniques are fast and convenient and correlate well with abdominal fat. Therefore, they are used in clinical practice as markers for visceral adiposity. ${ }^{16}$ However, they provide only an indirect assessment of adiposity, as they cannot differentiate between visceral and subcutaneous fat. $^{13,14}$ There has been only one study that evaluates the relationship between the amount of intraabdominal fat and the aortomesenteric angle and distance. ${ }^{10}$ Within this context, our study is the second in the literature. In the first study, Ozbulbul et al. found that the distance between the aorta and the SMA significantly correlates with the visceral fat area. However, there was no statistically significant relationship between the angle and the visceral fat area for males. We found a positive correlation between the amount of abdominal fat (expressed as MFT and RFT) and both the aortomesenteric angle and aortomesenteric distance. Ozbulbul et al. found that males have a greater proportion of visceral fat than females, but we did not find any differences according to gender in the present study.

Evaluation of visceral fat has been conducted using several imaging techniques, including CT, MRI and ultrasonography. Of these methods, evaluation using CT is the most useful and popular method. ${ }^{31 \text {, }}$ ${ }^{32}$ In our study, similar to Ozbulbul et al. we used CT to evaluate the amount of visceral fat. ${ }^{10}$ While Ozbulbul et al. used visceral fat area to assess the amount of visceral fat ${ }^{10}$, we used RFT and MFT.

Our study has some limitations. First, the patients were selected retrospectively. Second, the measurements were performed by a single researcher, and therefore there was no evaluation for interobserver variability. Third, the study group did not include any subjects with clinical findings of SMAS.

\section{CONCLUSION}

The distance and angle between the SMA and the aorta correlate with the retroperitoneal and mesenteric fat thickness. According to this result, retroperitoneal and mesenteric fat thickness may be used as an CT marker to help diagnose suspected SMAS in addition to the measurements of the distance and angle between the aorta and the SMA.

\section{REFERENCES}

1. Gustafsson L, Falk A, Lukes PJ, Gamklou R. Diagnosis and treatment of superior mesenteric artery syndrome. Br J Surg. 1984; 71: 499-501.

2. Alsulaimy M, Tashiro J, Perez EA, Sola JE. Laparoscopic Ladd's procedure for superior mesenteric artery syndrome. J Pediatr Surg. 2014; 49: 1533-35.

3. Applegate GR, Cohen AJ. Dynamic CT in superior mesenteric artery syndrome. J Comput Assist Tomogr 1988; 12: 976-80

4. Ahmed AR, Taylor I. Superior mesenteric artery syndrome. Postgrad Med 1997; 73:776-8.

5. Baltazar U, Dunn J, Floresguerra C, Schmidt L, Browder W. Superior mesenteric artery syndrome: an uncommon cause of intestinal obstruction. South Med J 2000; 93: 606-8.

6. Cohen LB, Field SP, Sachar DB. The superior mesenteric artery syndrome: the disease that isn't or is it? J Clin Gastroenterol 1985; 7: 113-6.

7. Jani PG. Superior mesenteric artery syndrome: case report. East Afr Med J 2003; 80: 334-6.

8. Matheus CO, Waisberg J, Toledo Zewer MH, Godoy AC. Syndrome of duodenal compression by 
the superior mesenteric artery following restorative proctocolectomy. A case report and review of literature. Sao Paulo Med J 2005; 123: 151-3.

9. Roy A, Gisel JJ, Roy V, Bouras EP. Superior mesenteric artery (Wilkie's) syndrome as a result of cardiac cachexia. J Gen Intern Med 2005; 20: C3-4

10. Ozbulbul N, Yurdakul M, Dedeoglu H, Tola M, Olcer T. Evaluation of the effect of visceral fat area on the distance and angle between the superior mesenteric artery and the aorta. Surg Radiol Anat. 2009; 31: 545-9.

11. Ozkurt H, Cenker MM, Bas N, Erturk SM, Basak M. Measurement of the distance and angle between the aorta and superior mesenteric artery: normal values in different BMI categories. Surg Radiol Anat. 2007; 29: 595-9.

12. Bhagirath Desai A, Sandeep Shah D, Jagat Bhatt C, Umesh Vaishnav K, Salvi B. Measurement of the Distance and Angle Between the Aorta and Superior Mesenteric Artery on CT Scan: Values in Indian Population in Different BMI Categories. Indian J Surg. 2015; 77: 614-7.

13. Schneider HJ, Glaesmer H, Klotsche J, Böhler S, Lehnert H, Zeiher AM, März W, Pittrow D, Stalla GK, Wittchen HU; DETECT Study Group. Accuracy of anthropometric indicators of obesity to predict cardiovascular risk. J Clin Endocrinol Metab. 2007; 92: 589-94.

14. Svendsen OL, Hassager C, Bergmann I, Christiansen C. Measurement of abdominal and intra-abdominal fat in postmenopausal women by dual energy X-ray absorptiometry and anthropometry: comparison with computerized tomography. Int J Obes Relat Metab Disord 1993; 17: 45-51.

15. Unal B, Aktas A, Kemal G. Bilgili Y, Güliter S, Daphan C, Aydinuraz K. Superior mesenteric artery syndrome: CT and ultrasonography endings. Diagn Interv Radiol 2005; 11: 90-5.

16. Yang L, Kuper $\mathrm{H}$, Weiderpass $\mathrm{E}$. Anthropometric characteristics as predictors of coronary heart disease in women. J Intern Med 2008; 264: 39-49.

17. Canoy D, Boekholdt SM, Wareham N, Luben R, Welch A, Bingham S, Buchan I, Day N, Khaw KT. Body fat distribution and risk of coronary heart disease in men and women in the European Prospective Investigation into Cancer and Nutrition in Norfolk cohort: a population-based prospective study. Circulation. 2007; 116: 293343.
18. Canoy D. Distribution of body fat and risk of coronary heart disease in men and women. Curr Opin Cardiol 2008; 23: 591-8.

19. Goodpaster BH, Krishnaswami S, Harris TB. Katsiaras A, Kritchevsky SB, Simonsick EM, Nevitt M, Holvoet P, Newman AB. Obesity, regional body fat distribution and the metabolic syndrome in older men and women. Arch Intern Med 2005; 165: 777-83.

20. Goodpaster BH, Krishnaswami S, Resnick H, Resnick H, Kelley DE, Haggerty C, Harris TB, Schwartz AV, Kritchevsky S, Newman AB. Association between regional adipose tissue distribution and both type 2 diabetes and impaired glucose tolerance in elderly men and women. Diabetes Care 2003; 26: 372-9.

21. Gillum RF. The association of body fat distribution with hypertension, hypertensive heart disease, coronary heart disease, diabetes and cardiovascular risk factors in men and women aged 18-79 years. J Chronic Dis 1987; 40: 421-8.

22. Uysal E, Paksoy Y, Koplay M, Nayman A, Gumus S. Effects of body mass index, mesenteric and abdominal subcutaneous adipose tissue on the spinopelvic parameters. Wien Klin Wochenschr 2015;127: 935-41.

23. Biswas A, Babu AA, Neelakantan S, Sarkar PS. Superior mesenteric artery syndrome: CT findings. BMJ Case Rep 2016 Jun 28 doi: 10.1136/bcr-2016215885.

24. Kaur A, Pawar NC, Singla S, Mohi JK, Sharma S. Superior mesentric artery syndrome in a patient with subacute intestinal obstruction: a case report, J Clin Diagn Res 2016; TD03-5.

25. Sherry Scovell M, Allen Hamdan M. Superior Mesenteric Artery Syndrome, 2015, Available at: E:ISMA syndrome reportl6-Superior mesenteric arterysyndrome. Uptodate.html. Accessed 08/2016, 2016.

26. Zaraket V, Deeb L. Wilkie's syndrome or superior mesenteric artery syndrome: fact or fantasy? Case Rep Gastroenterol 2015; 9: 194-9.

27. Merrett N.D, Wilson R.B, Cosman P, Biankin A.V. Superior mesenteric artery syndrome: diagnosis and treatment strategies, J. Gastrointest Surg 2009; 13: 287-92.

28. Shiu J.R, Chao H.C, Luo C.C, Lai M.W, Kong M.S, Chen S.Y. Clinical and nutritional outcomes in children with idiopathic superior mesenteric artery syndrome. J Pediatr Gastroenterol Nutr 2010; 51: 177-82. 
29. Welsch T, Buchler M.W, Kienle P. Recalling superior mesenteric artery syndrome. Dig Surg 2007; 24: 149-56.

30. Agrawal GA, Johnson PT, Fishman EK. Multidetector row $\mathrm{CT}$ of superior mesenteric artery syndrome. J Clin Gastroenterol 2007; 41: 62-5.

31. Hirooka M, Kumagi T, Kurose K, Nakanishi S, Michitaka K, Matsuura B, Horiike N, Onji M. A technique for the measurement of visceral fat by ultrasonography: comparison of measurements by ultrasonography and computed tomography. Intern Med 2005; 44; 794-9.

32. Yoshizumi T, Nakamura T, Yamane M. Islam AH, Menju M, Yamasaki K, Arai T, Kotani K, Funahashi T, Yamashita S, Matsuzawa Y. Abdominal fat: standartized technique for measurement at CT. Radiology 1999; 211: 283-6. 